University of Rhode Island

DigitalCommons@URI

Past Departments Faculty Publications (CELS) College of the Environment and Life Sciences

2002

\title{
The Horse and Deer Flies (Diptera: Tabanidae) of Rhode Island
}

\author{
Kristen Bartlett \\ University of Rhode Island \\ Steven R. Alm \\ University of Rhode Island, stevealm@uri.edu \\ Roger Lebrun \\ University of Rhode Island, rlebrun@uri.edu \\ Howard S. Ginsberg \\ University of Rhode Island, hginsberg@uri.edu
}

Follow this and additional works at: https://digitalcommons.uri.edu/cels_past_depts_facpubs

Creative Commons License

(c) (1) (9)

This work is licensed under a Creative Commons Attribution-Noncommercial 3.0 License

\section{Citation/Publisher Attribution}

Bartlett, K., Alm, S. R., Lebrun, R., \& Ginsberg, H. (2002). The Horse and Deer Flies (Diptera: Tabanidae) of Rhode Island. Annals of Entomological Society of America, 95(5), 547-551. doi: 10.1603/

0013-8746(2002)095[0547:THADFD]2.0.CO;2

Available at: http://dx.doi.org/10.1603/0013-8746(2002)095[0547:THADFD]2.0.C0;2

This Article is brought to you for free and open access by the College of the Environment and Life Sciences at DigitalCommons@URI. It has been accepted for inclusion in Past Departments Faculty Publications (CELS) by an authorized administrator of DigitalCommons@URI. For more information, please contact digitalcommonsgroup@uri.edu. 


\title{
The Horse and Deer Flies (Diptera: Tabanidae) of Rhode Island
}

\author{
KRISTEN BARTLETT, STEVEN R. ALM, ${ }^{1}$ ROGER LEBRUN, AND HOWARD GINSBERG ${ }^{2}$
}

Department of Plant Sciences, 9 E. Alumni Avenue, Suite 7, University of Rhode Island, Kingston, RI 02881

Ann. Entomol. Soc. Am. 95(5): 547-551 (2002)

\begin{abstract}
The Tabanidae of Rhode Island were surveyed using Rhode Island canopy traps placed at 20 locations in the state during the summers of 1999 and 2000. In total, 5,120 flies were collected, which included 55 species in the genera Chrysops, Hybomitra, Tabanus, Merycomyia, and Stonemyia. Distributional and ecological information is provided for each species in Rhode Island.
\end{abstract}

KEY WORDS Tabanidae, horse flies, deer flies, Rhode Island

HonSE FLIES AND deer flies (Diptera: Tabanidae) are recognized throughout the world as serious pests of humans and livestock. They are potentially mechanical vectors of several pathogens including Francisella tularensis (McCoy \& Chapin), and Bacillus anthracis Cohn (Krinsky 1976). Twenty Hybomitra lasiopthalma Macquart feeding on one cow are capable of consuming $\approx 2 \mathrm{ml}$ of blood (Pechuman 1981). Species abundance and distribution of Tabanidae have been reported from Connecticut (Fairchild 1950), New York (Pechuman 1981), Virginia (Pechuman 1973), Vermont (Pratt and Pratt 1986), Maine (Pechuman and Dearborn 1996), and Illinois (Pechuman et al. 1983), but not from Rhode Island. Here we provide a list of the species of horse flies and deer flies captured during a 2-yr survey in Rhode Island, along with information on abundance and distribution.

\section{Materials and Methods}

Twenty canopy traps were set throughout Rhode Island in state parks, preserves, salt marshes, and research facilities during 1 June to 16 September 1999 (Fig. 1). Traps in 1999 were set in Clarksville Pond (Glocester), Elle Pond (Hopkinton), Carolina Management Area (Richmond), Lincoln Woods (Lincoln), Wampanaug Trail (Barrington), Jacob’s Point Salt Marsh (Warren), Chapman Swamp (Westerly), Burlingame State Park, Beaver River (Charlestown), Round Marsh (Jamestown), Fogland Marsh (Little Compton), Seapowet Marsh (Tiverton), Beach Pond (Exeter), Larkin Pond, University of Rhode Island's East Farm (South Kingstown), Buck Hill and Black Hut Management Areas (Burrillville), and East Road - Scituate Reservoir (Scituate). Six traps were set in selected locations throughout Rhode Island during 1 June to 30 September 2000. Traps in 2000 were set

\footnotetext{
${ }^{1}$ E-mail: stevealm@uri.edu.

${ }^{2}$ USGS Patuxent Wildlife Research Center, Woodward Hall-PLS, University of Rhode Island, Kingston, RI 02881.
}

in Clarksville Pond, Ell Pond, Carolina Management Area, Chapman Swamp, University of Rhode Island's East and Peckham Farm's (South Kingstown) (Fig. 1).

The design for the Rhode Island canopy trap was modified from previous designs developed by Adkins (1972), Catts (1970), Thorsteinson et al. (1964) and Hribar et al. (1991). The Rhode Island canopy trap design implemented a mosquito breeder (BioQuip, Gardena, CA) as a collecting chamber. In addition, the canopy material was made of black Top Gun canvas (Marchem Coated Fabrics, New Haven, MO), which is resistant to mildew. Trap collecting chambers were emptied weekly. Flies were also collected using a sweep net along ponds, lakes, and dirt roads. Larvae were collected from the edges of various bodies of water as described by Freeman and Hansens (1972) and Teskey (1969). Larvae were reared to adults for further identification. Flies were pinned, labeled, and identified. Additional Tabanidae from the University of Rhode Island collection were examined. Keys by Pechuman $(1973,1981)$ and a catalog of horse and deer flies by Burger (1995) were used in the identification of tabanids. John F. Burger, University of New Hampshire, verified all identifications. Data, such as species, number of flies, locations, and dates, were recorded and tabulated.

\section{Results}

A total of 55 species in five genera was collected during the summers of 1999 and 2000. Each species is listed below along with information on collection sites and dates. Abundance was rated based on the total number of flies collected throughout both 1999 and 2000. Abundance was considered sparse if the number of flies collected ranged from 1 to 10, low (11-30), moderate (31-60), heavy (61-100), and very heavy (>100 flies) (Table 1). Sites with fewer species had greater average numbers of individuals per species than did sites with many species (Fig. 2). Tabanids 


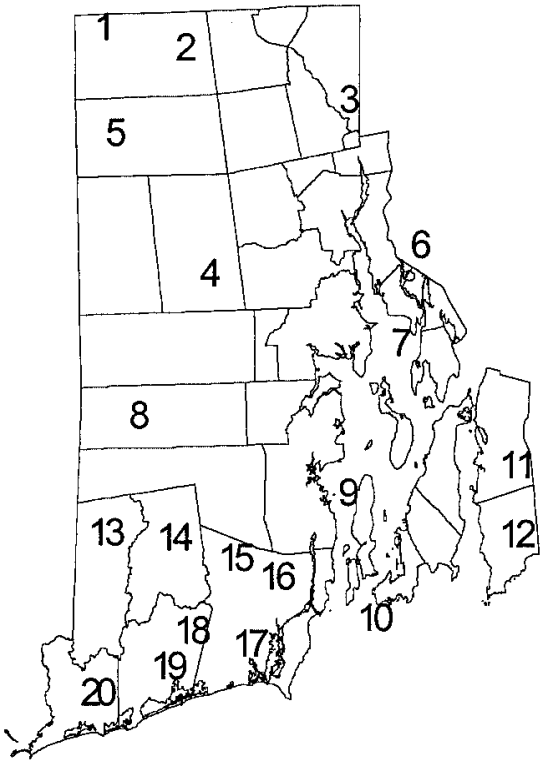

Fig. 1. Horse and deer fly trap locations in Rhode Island. Trap sites: Black Hut (1), Buck Hill (2), Lincoln Woods (3), Scituate Reservoir (4), Clarksville Pond (5), Wampanaug Trail (6), Jacob's Point (7), Beach Pond (8), Round Marsh (9 and 10), Seapowet Salt Marsh (11), Fogland Marsh (12), Ell Pond (13), Carolina Management Area (14), Larkin Pond (15 and 16), East Farm (17), Beaver River (18), Burlingame (19), and Chapman Swamp (20).

were present from May to September, and were most abundant during the early summer months (Fig. 3).

\section{Species Collected}

Chrysops aberrans Philip

Collection sites: Larkin Pond, Chapman Swamp, and Clarksville Pond.

Table 1. Species abundance in Rhode Island

\begin{tabular}{ll}
\hline \hline Abundance rating $^{a}$ & \multicolumn{1}{c}{ Species } \\
\hline Sparse (<11) & C. aberrans, C. atlanticus, C. callidus, C. \\
& carbonarius, C. celatus, C. cuclux, C. \\
& delicatulus, C. excitans, C. flavidus, C. \\
& fuliginosus, C. lateralis, C. moechus, C. \\
& montanus, C. niger, C. shermani, H. cincta, \\
& H. difficilis, H. pechumani, H. trispila, H. \\
& zonalis, M. whitneyi, S. rasa, T. \\
& americanus, T. atratus, T. catenatus, T. \\
& novascotiae, T. sackeni, T. sparus, T. \\
& stygius, T. sulcifrons, T. trimaculatus \\
C. cincticornis, C. geminatus, C. macquarti, & C. pudicus, C. sackeni, H. aurilimba, H. \\
Low (11-30) & epistates, T. quinquivittatus \\
Moderate (31-60) & C. dimmocki, T. marginalis, T. nigripes, T. \\
Heavy (61-100) & C. frigidumentarius, C. univittatus, C. vittatus, H. \\
Very heavy (>100) & sodalis \\
& H. hinei, H. lasiopthalma, T. conterminus, T. \\
& hinellus, T. lineola, T. nigrovittatus, T. \\
& pumilus \\
\hline
\end{tabular}

\footnotetext{
${ }^{a}$ Total number of flies collected, 1999 and 2000.
}

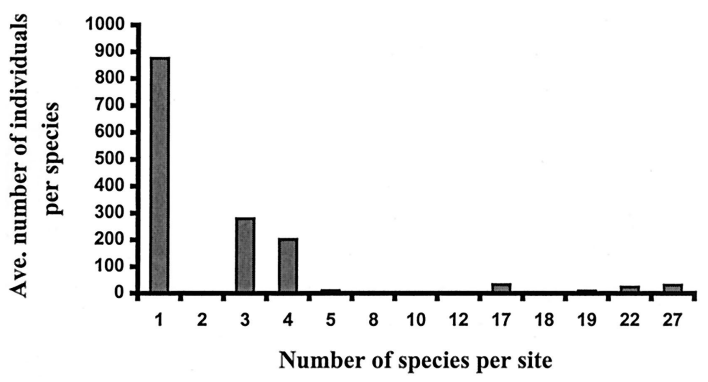

Fig. 2. Relative abundance of Tabanidae captured in canopy traps.

Collection dates: 25 June 1999; 2, 16, 21, and 26 July 1999; 4 August 1999; and 2 September 1999.

Chrysops atlanticus Pechuman

Collection site: Seapowet Salt Marsh.

Collection date: 9 August 1999.

Chrysops callidus Osten Sacken

Collection site: Great Swamp.

Collection date: 1 June 1999.

Chrysops carbonarius Walker

Collection site: Peckham Farm.

Collection date: 21 June 2000.

Chrysops celatus Pechuman

Collection site: Round Marsh.

Collection date: 9 August 1999.

Chrysops cincticornis Walker

Collection sites: Larkin Pond and Chapman Swamp.

Collection dates: 14 and 15 June 1999; 2 and 13 June 2000; and 20 July 2000.

Chrysops cuclux Whitney

Collection site: Peckham Farm.

Collection date: 15 June 2000.

Chrysops delicatulus Osten Sacken

Collection site: Clarksville Pond.

Collection date: 20 July 2000.

Chrysops dimmocki Hine

Collection sites: Chapman Swamp, Ell Pond, East Farm, and Larkin Pond.

Collection dates: 14, 15, 19, and 25 June 1999; 2, 6, and 16 July 1999; 16 August 1999; 10, 11, 21, and 25 July 2000; and 9 August 2000.

Chrysops excitans Walker

Collection site: Peckham Farm.

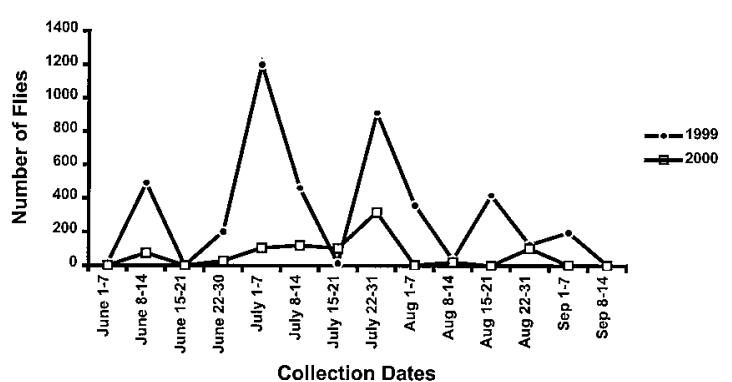

Fig. 3. Comparison of total number of Tabanidae collected in 1999 and 2000. 
Collection date: 15 June 2000.

Chrysops flavidus Wiedemann

Collection sites: East Farm, Clarksville Pond, and Ell Pond.

Collection dates: 19 and 25 June 1999; and 3 August 2000.

Chrysops frigidus Osten Sacken

Collection sites: Wakefield, Ell Pond, Chapman Swamp, Great Swamp, Larkin Pond, East Farm, and Burlingame State Park.

Collection dates: 14, 15, 25, and 28 June 1999; 2 and 6 July $1999 ; 4,5,11$, and 17 July 2000 ; and 2 September 1999.

Chrysops fuliginosus Wiedemann

Collection site: Great Swamp.

Collection date: 1 June 1999.

Chrysops geminatus Wiedemann

Collection sites: Clarksville Pond, Black Hut Management Area, Larkin Pond, Burlingame State Park, and East Farm.

Collection dates: 28 June 1999; 2, 6, 12, 16, and 21 July 1999; 11, 13, 19, 21, and 25 July 2000; and 9 August 2000.

Chrysops indus Osten Sacken

Collection site: Kingston.

Collection date: One specimen from URI collection from 1 July 1952.

Chrysops lateralis Wiedemann

Collection site: Peckham Farm.

Collection date: 21 July 2000.

Chrysops macquarti Philip

Collection sites: Larkin Pond, East Farm, and Carolina Management Area.

Collection dates: 25 June 1999; and 10, 12, 13, 14, 24, 25 , and 28, July 2000 .

Chrysops moechus Osten Sacken

Collection site: Kingston.

Collection date: One specimen from the URI collection from July of 1913.

Chrysops montanus Osten Sacken

Collection site: Clarksville Pond.

Collection date: 3 August 2000.

Chrysops niger Macquart

Collection site: Larkin Pond.

Collection date: 15 June 1999.

Chrysops pudicus Osten Sacken

Collection sites: Ell Pond, Clarksville Pond, East Farm, and Larkin Pond.

Collection dates: 19 and 25 June 1999; 12, 20, 24, and 25, July 2000.

Chrysops sackeni Hine

Collection sites: Peckham Farm, East Farm, Clarksville Pond, Larkin Pond, Ell Pond, and Chapman Swamp.

Collection dates: 15, 19, 25, and 28 June 1999; 2 July 1999 ; and 5, 14, and 20, July 2000.

Chrysops shermani Hine

Collection site: East Farm.

Collection date: 28 July 2000.

Chrysops univittatus Macquart

Collection sites: Larkin Pond, Black Hut Management, East Farm, and Carolina Management.
Collection dates: 25 June 1999; 2, 16, and 21 July 1999; $10,11,12,13,14,19,20,21,24,25$, and 28 July 2000 ; 2, 4, 6, 8, and 9 August 2000; and 2 September 1999.

Chrysops vittatus Wiedemann

Collection sites: Round Marsh, Chapman Swamp, Beaver River, Clarksville Pond, Black Hut Management Area, East Farm, and Larkin Pond.

Collection dates: 15 and 25 June 1999; 2, 6, 16, 19, 21, and 26 July 1999; 20, 21, 25, and 28 July $2000 ; 2$ and 16 August 1999; 4, 6, and 8 August 2000.

Hybomitra aurilimba Stone

Collection sites: Peckham Farm, Larkin Pond, Chapman Swamp, Burlingame State Park, and Seapowet Salt Marsh.

Collection dates: 2, 6, 12, 16, and 21 July 1999; and 24 July 2000 .

Hybomitra cincta $\mathrm{F}$.

Collection sites: Carolina Management Area, East Farm, and Clarksville Pond.

Collection dates: 21 July 1999; and 5, 10, 20, and 25 July 2000.

Hybomitra difficilis Wiedemann

Collection site: Ell Pond.

Collection date: 6 June 2000.

Hybomitra epistates Osten Sacken

Collection sites: East Farm, Chapman Swamp, Larkin Pond, Burlingame State Park, and Beaver River.

Collection dates: 13, 15, 25, and 28 June 2000; 2,6 , and 12 July 1999; 5 July 2000; and 10 and 11 July 2000.

Hybomitra hinei Johnson

Collection sites: East Farm, Chapman Swamp, Carolina Management, Burlingame State Park, and Beaver River.

Collection dates: 15, 25, and 28 June 1999; 2, 6, 16, 19 , and 28 July 1999; $5,11,12,13,14,21,24$, and 25 July 2000; and 16 August 1999.

Hybomitra lasiopthalma Macquart

Collection sites: East Farm, Carolina Management Area, Peckham Farm, Ell Pond, Chapman Swamp, Clarksville Pond, Great Swamp, Larkin Pond, Burlingame State Park, and Beaver River.

Collection dates: 1, 14, 16, 21, 25, and 28 June 1999; 2, $6,9,13$, and 14 June $2000 ; 2,6$, and 16 July 1999 ; and $5,10,11$, and 20 July 2000 .

Hybomitra pechumani Teskey \& Thomas

Collection site: Larkin Pond.

Collection dates: 25 June 1999 and 16 July 1999.

Hybomitra sodalis Williston

Collection sites: East Farm, Clarksville Pond, Ell Pond, Carolina Management Area, Chapman Swamp, Burlingame State Park, Seapowet Salt Marsh.

Collection dates: 28 June 1999; 2, 6, 12, 16, 19, 21, and 26 July $1999 ; 10,11,12,13,14,20,21,24$, and 25 July 2000; 4 August 1999; and 2, 3, 6, and 9 August 2000

Hybomitra trispila Wiedemann

Collection site: East Farm.

Collection dates: 10, 11, and 13 July 2000.

Hybomitra zonalis Kirby

Collection site: Ell Pond.

Collection date: 5 July 2000.

Merycomyia whitneyi Johnson

Collection site: Glocester. 
Collection dates: Larvae collected on 2 May and adults emerged 7 July 2000. An additional specimen was collected in canopy trap on 3 August 2000.

Stonemyia rasa Loew

Collection site: Glocester.

Collection date: 18 August 1999.

Tabanus americanus Forster

Collection sites: Chapman Swamp, and Larkin Pond.

Collection dates: 6 and 16 July 1999.

Tabanus atratus $\mathrm{F}$.

Collection sites: Wakefield and East Farm.

Collection dates: 21 July 1999; and 25 July 2000.

Tabanus catenatus Walker

Collection site: East Farm.

Collection date: 25 July 2000.

Tabanus conterminus Walker

Collection sites: Seapowet Salt Marsh, Round Marsh, Fogland Marsh, Jacob's Point Salt Marsh, and Wampanaug Trail.

Collection dates: 11, 19, 24, and 29 June 1999; 2, 6, 7, $12,14,16,19,21$, and 26 July 1999; 4, 9, 16, 23, and 29 August 1999; and 1 and 9 September 1999.

Tabanus hinellus $\mathrm{F}$.

Collection sites: Chapman Swamp, Jacob's Point Salt Marsh, East Farm, Burlingame State Park, Beaver River, Clarksville Pond, Black Hut Management Area, Buck Hill Management Area, and Larkin Pond.

Collection dates: 25 June 1999; 2, 6, 12, 16, 19, 21, and 26 July 1999; $5,10,11,12,13,14,19,20,21,25$, and 28 July 2000; 2 and 16 August 1999; and 2, 4, 6, 8, and 9 August 2000.

Tabanus lineola $\mathrm{F}$.

Collection sites: Chapman Swamp, Jacob's Point Salt Marsh, East Farm, Burlingame State Park, Beaver River, Clarksville Pond, Black Hut Management Area, Buck Hill Management Area, and Larkin Pond.

Collection dates: 25 June 1999; 2, 6, 12, 16, 19, and 26 July $1999 ; 5,10,11,12,13,14,19,20,21,25$, and 28 July 2000; 2 and 16 August 1999; 2, 4, 6, 8, and 9 August 2000.

Tabanus marginalis $\mathrm{F}$.

Collection sites: Peckham Farm, East Farm, Clarksville Pond, and Larkin Pond.

Collection dates: 15, 16, and 25 June 1999; 2 and 16 July 1999; 5, 7, and 24 July 2000; and 3 August 2000.

Tabanus nigripes Wiedemann

Collection sites: Chapman Swamp, East Farm, and Larkin Pond.

Collection dates: 25 and 28 June 1999; 2 , 12, and 16 July $1999 ; 10,11,12,13,14,25$, and 28 July 2000; 2 August 1999; 2 and 8 August 2000.

Tabanus nigrovittatus Macquart

Collection sites: Seapowet Salt Marsh, Round Marsh, Fogland Marsh, Jacob's Point Salt Marsh, Wampanaug Trail, Ell Pond, and Chapman Swamp.

Collection dates: 11, 19, 24, and 29 June 1999; 2, 6, 7, $12,14,16,19,21$, and 26 July 1999; 4, 9, 16, 23, and 29 August 1999; and 1 and 9 September 1999.

Tabanus novaescotiae Macquart

Collection site: East Farm.
Collection date: 22 August 2000.

Tabanus pumilus Macquart

Collection sites: Carolina Management Area, Peckham Farm, East Farm, Clarksville Pond, Chapman Swamp, Larkin Pond, Ell Pond, and Burlingame State Park.

Collection dates: 14, 15, 19, and 25 June 1999; 2, 6, 12 , 16 , and 26 July $1999 ; 5,10,11,12,13,14,19,20,21$, 24, 25, and 28 July 2000; 2 and 16 August 1999; and 2, 4, and 8 August 2000.

Tabanus quinguivittatus Weidemann

Collection site: East Farm.

Collection dates: 10, 14, and 21 July 2000; and 2 and 8 August 2000.

Tabanus sackeni Fairchild

Collection site: Carolina Management Area.

Collection date: 16 August 1999.

Tabanus sparus Whitney

Collection site: East Farm.

Collection date: 28 July 2000.

Tabanus stygius Say

Collection site: Great Swamp.

Collection date: 4 July 2000.

Tabanus sulcifrons Macquart

Collection site: East Farm.

Collection dates: 6 and 8 September 2000.

Tabanus superjumentarius Whitney

Collection sites: East Farm, Ell Pond, and Larkin Pond.

Collection dates: 25 June 1999; 2 and 16 July 1999; 10,

$11,12,13,14,20,21,24$, and 25 July $2000 ; 2,4,8$, and 9 August 2000.

Tabanus trimaculatus Palisot de Beauvois

Collection site: East Farm.

Collection date: 2 August 2000.

\section{Discussion}

This is a comprehensive survey of the tabanids of Rhode Island. A total of 5,305 flies was collected the summers of 1999 and 2000 including 55 species in five genera. Of these species, only a few were heavy in abundance. Also, sites with fewer species had greater average numbers of individuals per species than did sites with many species. Salt marshes had fewer species with high abundance, while forested sites near swamps or lakes had many more species but fewer numbers of flies. The majority of tabanids collected (71\%) were from the genus Tabanus. Chrysops made up $7 \%$ of the trap catch, Hybomitra $22 \%$. Only one specimen of Stonemyia and two of Merycomyia were collected. The majority of species collected in this study were of sparse or low abundance. Among the heavy to very heavily abundant species are Chrysops frigidus, C. univittatus, C. vittatus, Hybomitra hinei, $H$. lasiopthalma, H. sodalis, Tabanus hinellus, T. lineola, T. nigrovittatus, T. conterminus, and T. pumilus. Tabanus nigrovittatus and T. conterminus (57\% of all flies collected) were consistently abundant throughout the summer collecting season.

Hybomitra lasiopthalma, a severe pest of livestock, was found in several trap sites and habitats throughout Rhode Island at the beginning of the summer. This 
species is one of the earliest to emerge in Rhode Island, peaks at very high numbers, and completely disappears toward the second week of July. Other early season species include Chrysops cincticornis, C. carbonarius, and C. niger. These early season species of Chrysops are some of the first species to emerge, and share unique taxonomic characteristics. They are each dark species, and have no apical spot on the wing.

The northern and southern locations in Rhode Island showed similar species distribution and abundance. There was no difference in trap dates for species collected in the northern and southern parts of Rhode Island. Heavy and very heavily abundant species were abundant in all counties regardless of trap location.

Species phylogenies in this survey suggest that abundance peaks at the end of June and the beginning of July. By understanding tabanid population dynamics, as indicated by the number of host seeking tabanids trapped in host-mimicking traps, better protective measures can be implemented at times when aggressive human or livestock biters are most abundant.

\section{References Cited}

Adkins, T. R. 1972. A modified canopy trap for collecting Tabanidae (Diptera). J. Med. Entomol. 9: 183-185.

Burger, J. F. 1995. Catalog of Tabanidae (Diptera) of North America north of Mexico. Int. Contrib. Entomol. 1: 1-100.

Catts, E. P. 1970. A canopy trap for collecting Tabanidae. Mosq. New. 30: 472-474.

Fairchild, G. B. 1950. Family Tabanidae. Guide to the insects of Connecticut. Part VI. The Diptera or true flies of
Connecticut 4th Fascicle. State Geol. Nat. Hist. Surv. 75: $1-31$.

Freeman, J. V., and E. J. Hansens. 1972. Collecting larvae of the salt marsh greenhead Tabanus nigrovittatus and related species in New Jersey: comparison and methods. Environ. Entomol. 1: 653-658.

Hribar, L. J., D. J. Leprince, and L. D. Foil. 1991. Design for a canopy trap for collecting horse flies (Diptera: Tabanidae). J. Am. Mosq. Control Assoc. 7: 657-659.

Krinsky, W. L. 1976. Animal disease agents transmitted by horse flies and deer flies (Diptera:Tabanidae). J. Med. Entomol 13: 225-275.

Pechuman, L. L. 1973. The Insects of Virginia: No. 6. Horse flies and deer flies of Virginia (Diptera: Tabanidae). Va. Polytechnic Inst. State Univ. Res. Div. Bull. 81: 1-92.

Pechuman, L. L. 1981. Horse flies and deer flies of New York (Diptera: Tabanidae). Search Agric. 18.

Pechuman, L. L., and R. Dearborn. 1996. The horse flies and deer flies of Maine (Diptera: Tabanidae). Technical Bulletin 160. Maine Agricultural and Forest Experiment Station, University of Maine, Orono.

Pechuman, L. L., D. W. Webb, and H. J. Teskey. 1983. The Diptera, or true flies, of Illinois. I. Tabanidae. Ill. Nat. Hist. Surv. Bull. 33: 1-121.

Pratt, G. K., and H. D. Pratt. 1986. Notes on deer flies and horse flies (Diptera: Tabanidae) from Southern Vermont. J. Am. Mosq. Control Assoc. 2: 365-367.

Teskey, H. J. 1969. Larvae and pupae of some eastern North American Tabanidae (Diptera). Mem. Entomol. Soc. Can. 63.

Thorsteinson, A. J., G. B. Bracken, and W. Hanec. 1964. The Manitoba horse fly trap. Can. Entomol. 96: 166.

Received for publication 28 August 2001; accepted 8 February 2002 